\title{
Ubezpieczenie od następstw nieszczęśliwych wypadków i chorób dla dzieci rolników ubezpieczonych w KRUS
}

1. Kwestia ochrony dzieci pracujących w gospodarstwach rolnych nie została dotąd kompleksowo rozwiązana w systemie rolniczego ubezpieczenia społecznego. Choć pierwsze akty prawne chroniące rolników przed utratą zdolności do pracy $\mathrm{w}$ tytule sugerowały ochronę rodziny ${ }^{1}$, to wprowadzane w nich rozwiązania nie dotyczyły w praktyce tej materii. Obecnie obowiązująca ustawa o ubezpieczeniu społecznym rolników z 1990 r. ${ }^{2}$, przed nowelizacją w 2004 r. $^{3}$, zawierała swoistą konstrukcję ochrony dzieci do lat 16 pracujących w rolnictwie. Mimo że podmioty te nie podlegały ubezpieczeniu w Kasie Rolniczego Ubezpieczenia Społecznego (KRUS), w razie wystąpienia wypadku miały prawo do świadczeń z ubezpieczenia rodzica. Zgodnie z danymi gromadzonymi przez KRUS odnotowywano wówczas średnio 1400 wypadków dzieci rocznie ${ }^{4}$.

Sytuacja zmieniła się z chwilą wejścia w życie ustawy nowelizującej przepisy rolniczego ubezpieczenia społecznego ${ }^{5}$. Dnia 2 maja 2004 r. dzieci

* Wydział Ekonomiczny, Uniwersytet Przyrodniczy w Poznaniu.

${ }^{1}$ Ustawa z 14 grudnia 1982 r. o ubezpieczeniu społecznym rolników indywidualnych i ich rodzin (Dz. U. Nr 40, poz. 268 z późn. zm.); ustawa z 24 lutego 1989 r. o zmianie ustawy o ubezpieczeniu społecznym rolników indywidualnych i ich rodzin (Dz. U. Nr 10, poz. 105).

${ }^{2}$ Ustawa z 20 grudnia 1990 r. o ubezpieczeniu społecznym rolników (tekst jedn. Dz. U. 2020, poz. 174 ze zm., dalej: u.u.s.r.).

3 Dz. U. 1991, nr 7, poz. 24.

${ }^{4}$ Dane uzyskane z Centrali KRUS w Warszawie.

${ }^{5}$ Ustawa z 2 kwietnia 2004 r. o zmianie ustawy o społecznym ubezpieczeniu rolników oraz o zmianie niektórych ustaw (Dz. U. Nr 91, poz. 873). 
poniżej 16. roku życia zostały całkowicie pozbawione ochrony podczas wykonywania prac w działalności rolniczej. Ustawodawca zrezygnował bowiem z poprzednio obowiązującej konstrukcji. Podmioty te nie mogły być także wnioskowo objęte ubezpieczeniem społecznym w KRUS. Zmiany ustawodawca motywował koniecznością wyeliminowania pracy dzieci w rolnictwie, by zjawisko to z powszechnego stało się marginalne. Pośrednim skutkiem omawianych zmian było zaniechanie przez KRUS opracowywania statystyk uwzględniających wypadki dzieci.

Zagadnienie ochrony dzieci w rolnictwie było wielokrotnie poruszane w doktrynie ${ }^{6}$. Wskazywano na rozwiązania krajów Europy Zachodniej, postulując potrzebę ochrony najmłodszych przed wypadkami przy pracy. Ustawodawca nie rozwiązał jednak tego problemu.

Poruszana kwestia została dostrzeżona przez KRUS. W 2016 r. władze Funduszu Składkowego Ubezpieczenia Społecznego Rolników (FSUSR) zawarły umowę ${ }^{7}$ o prywatne ubezpieczenie gospodarcze na grupowe ubezpieczenia następstw nieszczęśliwych wypadków i chorób dzieci ${ }^{8}$. Ubezpieczenie to przeznaczone było dla dzieci osób objętych społecznym ubezpieczeniem rolników i zostało w całości sfinansowane ze środków FSUSR. Ta praktyka stosowana jest do dziś.

Artykuł stanowi odpowiedź na pytanie, na ile ubezpieczenie od następstw nieszczęśliwych wypadków zapewnia dzieciom pomagającym rodzicom w działalności rolniczej ochronę przed wystąpieniem skutków zdarzeń losowych. Z uwagi na swoistą konstrukcję ubezpieczenia należy przeprowadzić analizę porównawczą zakresu ochrony przyznanej w ubezpieczeniu od następstw nieszczęśliwych wypadków i niektórych chorób dzieci $\mathrm{z}$ rozwiązaniami przyjętymi $\mathrm{w}$ rolniczym ubezpieczeniu społecznym. Nie jest to jednak zadanie łatwe $z$ uwagi na inny zakres ubezpieczenia. Rozważania porównawcze obejmą zatem ubezpieczenie chorobowe i wypadkowe w rolniczym ubezpieczeniu społecznym. Trzeba zatem określić przedmiot

${ }^{6}$ M. Skąpski, Wybrane zagadnienia wspótpracy zawodowej rodziców i dzieci, „Ubezpieczenia w Rolnictwie. Materiały i Studia” 1999, nr 4, s. 42 i nn.; S. Lachowski, Uregulowania prawne możliwości angażowania dzieci do pracy w rodzinnym gospodarstwie rolnym, w: J Zagórski, S. Lachowski, Zagrożenia zdrowia dzieci angażowanych do prac w rodzinnym gospodarstwie rolnym, Lublin 1999, s. 24 i nn.; M.A. Król, Rozwiąania prawne w zakresie zabezpieczenia warunków pracy kobiet i przeciwdziałania wypadkom z udziałem dzieci w rolnictwie w aktach międzynarodowych $i$ wybranych państwach europejskich, „Ubezpieczenia w Rolnictwie. Materiały i Studia" 2015, nr 53, s. 91-99; D. Puślecki, Prawna ochrona dzieci pracujacych w rodzinnym gospodarstwie rolnym na tle rozwiazań przyjętych $w$ wybranym ustawodawstwie europejskim, w: A. Stelmach i inni, Stosunki międzynarodowe w procesie zmian, Poznań 2018, s. 441 i nn.

7 Umowa ta została zawarta przez FUUSR z Ergo Hestia.

${ }^{8}$ Suma ubezpieczenia została określona w umowie na kwotę 67000 zł. 
ochrony tych ubezpieczeń i zakres podmiotowy, a następnie przeanalizować zakres zdarzeń chronionych oraz katalog świadczeń mogących przysługiwać poszkodowanym. Nie można też pominąć kwestii określenia granic odpowiedzialności ubezpieczyciela ze szczególnym uwzględnieniem przesłanek pozbawiających prawa do świadczeń.

2. Zgodnie z danymi publikowanymi przez International Social Security Association (ISSA) ${ }^{9}$ dwie trzecie dzieci, które giną w europejskich gospodarstwach rolnych, ma poniżej 5 lat, a najczęstszą przyczyną ich śmierci są zdarzenia z udziałem pojazdów. Wśród innych przyczyn wypadków śmiertelnych ISSA wskazuje: maszyny, utonięcia, uduszenia, kontakt ze zwierzętami. Najczęstszymi przyczynami wysokiego wskaźnika wypadków śmiertelnych są: niezrozumienie zagrożenia przez rolników, rodziców i dzieci, niewłaściwe szkolenie i nadzór, niewłaściwie zabezpieczone miejsca zabaw ${ }^{10}$.

Wypadki przy pracy w działalności rolniczej występują znacznie częściej niż w przemyśle czy handlu. Zdarzeniom wypadkowym ulegają nie tylko rolnicy, ale także inne osoby pomagające im w działalności rolniczej ${ }^{11}$. Rolnicze ubezpieczenie wypadkowe nigdy nie obejmowało ochroną ubezpieczeniową wypadków osób najbliższych niezwiązanych z pracą rolniczą. Zdarzenia wypadkowe w rolnictwie z uwagi na rodzinny, wielopokoleniowy charakter gospodarstw rolnych są poważnym problemem społecznym. Konieczność ochrony osób, które pomagają rolnikom w jednym z najniebezpieczniejszych sektorów gospodarki nie powinna więc budzić wątpliwości ${ }^{12}$.

Zgodnie z art. 23 Konstytucji RP z 1997 r. podstawą ustroju rolnego państwa jest gospodarstwo rodzinne. Konstytucyjne uznanie „gospodarstwa rodzinnego" za podstawę ustroju odpowiada faktycznemu stanowi rzeczy, jaki ukształtował się w rozwoju historycznym naszego rolnictwa ${ }^{13}$. Uzna-

${ }^{9}$ Organizacja powstała w 1927 r. z siedzibą w Genewie w Szwajcarii. Jest to największa na świecie międzynarodowa organizacja skupiająca instytucje zabezpieczenia społecznego (www. issa.int). KRUS jest członkiem ISSA od 1992 r. Dane na podstawie: Protecting health and safety of workers in agriculture, livestock farming, horticulture and forestry, European Commission, Luxembourg 2012, s. 51.

${ }^{10}$ Szerzej na ten temat M.A. Król, Rozwiąania prawne..., s. 85-86.

${ }^{11}$ Chodzi tu także o podmioty, z którymi rolnik zawarł cywilnoprawną umowę o pomoc przy zbiorach. Obowiązujące od 18 maja 2018 r. znowelizowane przepisy w zakresie ubezpieczenia społecznego rolników zawiera ustawa z 13 kwietnia 2018 r o zmianie ustawy o ubezpieczeniu społecznym rolników oraz niektórych innych ustaw (Dz. U. poz. 858).

12 Wskaźnik wypadkowości przy pracy w rolnictwie w 2017 r. wyniósł 8,5 zdarzeń na 1000 ubezpieczonych, www.krus.gov.pl [dostęp: 12.05.2020].

13 A. Stelmachowski, Modele własności i ich uwarunkowania społeczno-ustrojowe, w: E. Gniewek (red.), Prawo rzeczowe. System prawa prywatnego, t. 3, Warszawa 2013, s. 217-336. 
nie gospodarstwa rodzinnego za „podstawę” ustroju oznacza, że jest ono „zasadniczym elementem” tego ustroju ${ }^{14}$. W normie konstytucyjnej zawarte jest przekonanie, że ten stan rzeczy będzie utrzymany także w przyszłości ${ }^{15}$.

Istotną cechą działalności rolniczej jest jej silny, nierozerwalny związek z gospodarstwem domowym. Wiąże się to nie tylko z problemami kwalifikacji zdarzeń ubezpieczeniowych, lecz także z kwestią akceptacji pracy i pomocy dzieci rolnika w tym gospodarstwie. Nie można też zapominać, że są w Polsce gospodarstwa o typowo socjalnym, zaopatrzeniowym charakterze, które nie funkcjonują wcale, bądź tylko w marginalnym zakresie, na rynku. To wyjątkowa cecha działalności rolniczej - odróżniająca rolnika od typowego przedsiębiorcy. Swoiste są także kategorie ryzyka socjalnego, które towarzyszą tak zakreślonej działalności.

3. Zmiany ustawowe dokonane w $2004 \mathrm{r}$. spowodowały funkcjonowanie w rolnictwie podmiotów narażonych na liczne zagrożenia, nieubezpieczonych i pozbawionych ochrony na wypadek nieszczęśliwych zdarzeń losowych ${ }^{16}$. Problem ten istniał od 12 lat, aż Zarząd Funduszu Składkowego postanowił objąć dzieci ochroną, zawierając umowę z prywatnym towarzystwem ubezpieczeniowym na grupowe ubezpieczenie gospodarcze ${ }^{17}$. Efektem tych działań było powstanie nieznanej wcześniej konstrukcji w systemie rolniczego ubezpieczenia społecznego ${ }^{18}$. Rozwiązanie to zasługuje na uznanie z uwagi na do dziś istniejący problem organizacji grupowych ubezpieczeń NNW w szkołach podstawowych ${ }^{19}$ (ubezpieczenie to zawsze było dobrowolne,

${ }^{14}$ A. Lichorowicz, Konstytucyjne podstawy ustroju rolnego RP w świetle art. 23 Konstytucji, „Studia Iuridica Agraria” 2000, t. I, s. 23-45.

15 S. Prutis, Status prawny rodzinnego gospodarstwa rolnego w polskim prawie rolnym (ocena stanu regulacji), w: P. Litwiniuk (red.), Prawne mechanizmy wspierania i ochrony rolnictwa rodzinnego w Polsce i innych państwach Unii Europejskiej, Warszawa 2015, s. 11.

16 Szerzej: D. Puślecki, Kwestia ochrony osób bliskich rolnikowi od wypadków przy pracy w świetle rozwiqzań ustawy o ubezpieczeniu społecznym rolników, w: Z. Niedbała (red.), Prawo wobec dyskryminacji w życiu społecznym, gospodarczym i politycznym, Warszawa 2011, s. 239-263.

${ }_{17}$ Ubezpieczenia te cechuje prostota, łatwość zawarcia i przystąpienia do umowy, są one z reguły organizowane przez kierownictwo zakładu pracy, związku zawodowego lub innej organizacji tworzącej grupę. E. Stroiński, Ubezpieczenia na życie, Warszawa 2003, s. 277-283.

${ }_{18}$ W kwestii ubezpieczeń na życie zob. D. Sługocka, M. Podstawka, Ubezpieczenia grupowe w systemie ubezpieczeń społecznych (na przykładzie Towarzystwa Ubezpieczeń SIGNAL IDUNA Życie Polska S.A.), „Zeszyty Naukowe SGGW - Ekonomika i Organizacja Gospodarki Żywnościowej” 2006, nr 58, s. 55.

19 Szerzej: Ubezpieczenie NNW dzieci i młodzieży w szkolnej. Problemy w praktyce obrotu, Rzecznik Finansowy, https://archiwum.rf.gov.pl/z-prac-biura/Ubezpieczenie_NNW_dzieci_i_ mlodziezy_szkolnej_i_akademickiej_2874 [dostęp: 5.05.2020]. 
cechowało się niskimi sumami ubezpieczenia: 5-10 tys. zł i niewiele dzieci wiejskich było nim objętych).

Umowa ubezpieczenia NNW i chorób dzieci zawierana jest przez FSUSR na okres roku ${ }^{20}$. Grupowe ubezpieczenie $\mathrm{NNW}^{21}$ obejmuje w zakresie podmiotowym wyłącznie dzieci rolników do ukończenia 16. roku życia i pozostające we wspólnym gospodarstwie domowym z rodzicami lub opiekunami prawnymi, z których przynajmniej jedno podlega ubezpieczeniu społecznemu rolników w pełnym zakresie ${ }^{22}$.

Przyjęte przez FSUSR rozwiązanie może stwarzać pozory, a nawet niebezpieczeństwo utwierdzenia w przekonaniu o rozwiązaniu istniejącego od 2004 r. problemu ochrony dzieci przed utratą zdolności do pracy. Jest to jednak ubezpieczenie gospodarcze i nie może zapewnić takiej samej ochrony jak ubezpieczenie społeczne. Analizowane rozwiązanie ma więc charakter fragmentaryczny, niekompletny. Nie może bowiem zapewnić dzieciom odpowiedniej ochrony ani ex ante, ani ex post. Nie chroni zdolności do pracy, lecz życie i zdrowie dziecka przed skutkami nieszczęśliwych wypadków. Nie skupia się na ochronie dzieci pracujących w rolnictwie, a na zdarzeniach mogących skutkować utratą życia i zdrowia.

W przypadku rolniczego ubezpieczenia społecznego mamy do czynienia z ryzykiem socjalnym. Pojęcie ryzyka przejęte przez ubezpieczenie społeczne jest szersze od tego występującego w ubezpieczeniach gospodarczych. Zdarzenie ubezpieczeniowe to zdarzenie przyszłe, często niepewne, niezależne od woli człowieka i niekorzystne w skutkach. Na zakres przysługującej ochrony wpływ ma cała regulacja prawna: od teoretycznych podstaw ubezpieczenia, instytucji ubezpieczeniowej, przedmiotu ochrony, poprzez zakres podmiotowy i przedmiotowy, kwalifikacje zdarzeń, katalog świadczeń, aż do rozstrzygania sporów przez sąd. Ochrona ta powinna być zapewniona nie tylko ex post, poprzez przyznanie i wypłatę świadczeń, ale przede wszystkim ex ante, czyli przed wystąpieniem zdarzenia ubezpieczeniowego.

Funkcja ochronna ubezpieczenia społecznego wywodzi się z potrzeby ochrony ludzi pracujących, a więc $\mathrm{z}$ ustawodawstwa ochronnego pracy. Jej celem jest zabezpieczenie rolnika, jego małżonka i domownika, a więc każdego ubezpieczonego przed ryzykiem niekorzystnych dla niego zdarzeń losowych mogących wystąpić podczas prowadzenia działalności rolniczej. Przedmiotem ochrony rolniczego ubezpieczenia społecznego jest ochrona

20 Jest to aktualna umowa zawarta przez Zarząd FSUSR z Pocztowym Towarzystwem Ubezpieczeń Wzajemnych na okres od 1 stycznia do 31 grudnia $2020 \mathrm{r}$.

${ }^{21}$ Szerzej: M. Fras, Grupowe ubezpieczenie, Warszawa 2015, s. 37 i nn.

${ }^{22}$ Ubezpieczenie obejmuje 460 tys. podmiotów. Dane Ergo Hestia za 2016 rok. 
przed skutkami niekorzystnych zdarzeń losowych mogących zagrozić zdobywaniu przez człowieka własną pracą środków utrzymania. Zdarzenia te obejmują wypadki przy pracy, choroby zawodowe, osiągnięcie wieku poprodukcyjnego i niemożność wykonywania pracy z powodu macierzyństwa. Podstawową funkcją ubezpieczeń społecznych jest funkcja ochronna.

Rolnicze ubezpieczenia społeczne są częścią zabezpieczenia społecznego, a realizacja zadań objęta jest gwarancją państwa. Funkcja gwarancyjna tego ubezpieczenia polega na tym, że ubezpieczony-poszkodowany może liczyć na świadczenie w każdym przypadku przewidzianym w obowiązującej regulacji po spełnieniu przesłanek wskazanych w ustawie. Funkcja kompensacyjna polega na przyznawaniu świadczeń poszkodowanym według ustawowo określonych katalogów świadczeń. Ich jakość (wysokość) określana jest przy udziale Rady Rolników. Funkcja prewencyjna polega natomiast na zapobieganiu zdarzeń losowych, które mogą występować w działalności rolniczej. Choć w przypadku KRUS zachowanie właściwej relacji między prewencją prawną a realnym działaniem może być dyskusyjne, to warto wskazać na działania KRUS w postaci szkoleń oraz zaleceń prewencyjnych, organizowanych akcji i konkursów poświęconych bezpieczeństwu przy pracy.

Przedmiotem ochrony w ubezpieczeniu od następstw nieszczęśliwych wypadków są szkody na osobie zagrażające życiu i zdrowiu człowieka. W przeciwieństwie do obowiązkowego ubezpieczenia społecznego jest to, poza nielicznymi wyjątkami, dobrowolne ubezpieczenie osobowe ${ }^{23}$. Zawarcie umowy między FSUSR a towarzystwem ubezpieczeniowym nie powoduje, że jest to ubezpieczenie dobrowolne. Do powstania stosunku ubezpieczenia nie jest wymagane złożenie wniosku przez zainteresowanego rodzica czy opiekuna dziecka. Stosunek ubezpieczenia dziecka rolnika powstaje z tytułu podlegania jego rodzica albo opiekuna prawnego ubezpieczeniu w KRUS według zasady solidaryzmu rolników, na podstawie umowy zawartej i samofinansowanej przez FSUSR.

Potwierdzeniem zawarcia umowy ubezpieczenia jest zaświadczenie wystawione przez KRUS, informujące o tym, że rodzic lub opiekun prawny dziecka jest objęty ubezpieczeniem społecznym rolników w pełnym zakresie (ubezpieczeniem emerytalno-rentowym oraz ubezpieczeniem wypadkowym,

23 Jako wyjątek od tej reguły ustawodawca przewidział obowiązek zawarcia ubezpieczenia NNW dla niektórych grup podmiotów (np. klientów organizatorów turystyki lub pośredników turystycznych, zawodników sportowych, żołnierzy, funkcjonariuszy Biura Ochrony Rządu, wolontariuszy, skazanych, wykonujących nieodpłatną, kontrolowaną pracę na cele społeczne oraz pracę społecznie użyteczną). 
chorobowym i macierzyńskim) w KRUS lub był objęty tym ubezpieczeniem w okresie polisowym.

Ubezpieczenie NNW należy do grupy ubezpieczeń osobowych. Nie można go zakwalifikować do ubezpieczeń na życie, gdyż poza podobnym przedmiotem ochrony ubezpieczeniowej (życiem, zdrowiem) inne istotne elementy umowne określane są $\mathrm{w}$ sposób zbliżony do ubezpieczeń majątkowych. W ubezpieczeniu następstw nieszczęśliwych wypadków prawo do świadczenia zależy od doznania przez osobę ubezpieczoną nieszczęśliwego wypadku, powodującego skutki określone każdorazowo w warunkach ubezpieczenia ${ }^{24}$.

Ubezpieczenie NNW oferuje ochronę ubezpieczeniową w przypadku doznania przez ubezpieczonego określonych w umowie skutków nieszczęśliwego wypadku. Ma na celu finansowe wsparcie ubezpieczonego lub jego bliskich w przypadku wystąpienia u poszkodowanego trwałego uszczerbku na zdrowiu lub śmierci wskutek nieszczęśliwego wypadku. Jednak w przeciwieństwie do ustawy o ubezpieczeniu społecznym rolników pojęcie nieszczęśliwego wypadku nie zostało zdefiniowane w przepisach prawa. W związku $\mathrm{z}$ tym strony ubezpieczenia mają swobodę przy definiowaniu tego pojęcia, a definicje te często się różnią w ogólnych warunkach ubezpieczenia (OWU) oferowanych przez poszczególne zakłady ubezpieczeń ${ }^{25}$.

4. Na prawo ubezpieczeń gospodarczych składają się normy regulujące stosunki związane z zawieraniem i wykonywaniem umów ubezpieczenia ${ }^{26}$. Ze względu na jedność przedmiotową jest ono często traktowane w doktrynie jako wyodrębniona dziedzina prawa ${ }^{27}$. Umowa ubezpieczenia NNW, poza unormowaniami ogólnymi, nie doczekała się jednak szczegółowej regulacji. Stosunek ubezpieczenia zależy od woli stron, przy znaczącej roli OWU, które stanowią integralną część umowy.

Do określenia zakresu ochrony przyznanej przez ubezpieczyciela dzieciom rolnika niezbędna jest analiza ogólnych warunków umowy ubezpiecze-

${ }^{24}$ B. Adamczyk-Kloczkowska (red.), Ubezpieczenia osobowe, Warszawa 2008, s. 51.

${ }^{25}$ R. Grabiec, Ubezpieczenia w teorii i praktyce, t. II, Częstochowa 2016, s. 35 i nn.

${ }^{26}$ Materię tę regulują m.in.: ustawa z 22 maja 2003 r. o pośrednictwie ubezpieczeniowym (Dz. U. 2014, poz. 1450 z późn. zm.); ustawa z 22 maja 2003 r. o nadzorze ubezpieczeniowym i emerytalnym oraz Rzeczniku Ubezpieczonych (Dz. U. 2013, poz. 290 z późn. zm.); ustawa z 22 maja 2003 r. o działalności ubezpieczeniowej (Dz. U. 2015, poz. 1206 z późn. zm.); ustawa z 22 maja 2003 r. o ubezpieczeniach obowiązkowych, Ubezpieczeniowym Funduszu Gwarancyjnym i Polskim Biurze Ubezpieczycieli Komunikacyjnych (Dz. U. 2013, poz. 392 z późn. zm.).

${ }^{27}$ Tak: E. Kowalewski, Prawo ubezpieczeń gospodarczych, Bydgoszcz - Toruń 2006, s. $84-85$. 
nia grupowego ${ }^{28}$. Za nieszczęśliwy wypade ${ }^{29} \mathrm{~W}$ myśl postanowień umowy ubezpieczenia uważa się nagłe zdarzenie wywołane przyczyną zewnętrzną, niezależne od woli i stanu zdrowia ubezpieczonego, w wyniku którego doznał uszkodzenia ciała, rozstroju zdrowia albo zmarł. Za nieszczęśliwy wypadek uważa się również zawał serca i udar mózgu. Nie uznaje się tu jednak innych chorób, nawet tych występujących nagle. Tak określone pojęcie jest szersze od definicji wypadku zawartej w ustawie ubezpieczeniowej. Obejmuje bowiem zawał serca i udar mózgu, które są wywoływane właściwościami organizmu i stanowią wewnętrzną przyczynę zdarzenia wypadkowego.

Zakres analizowanego ubezpieczenia obejmuje skutki nieszczęśliwych wypadków, w tym komunikacyjnych, i wskazanych w umowie chorób. W odniesieniu do wypadków świadczenia mogą przysługiwać z tytułu śmierci dziecka, uszczerbku na zdrowiu, uszkodzenia ciała, porażenia prądem, zatrucia, pokąsania, ukąszenia, pogryzienia, ugryzienia dziecka przez zwierzęta, powypadkowego wstrząśnienia mózgu, oparzenia i odmrożenia ciała.

W przypadku śmierci dziecka zakres przyznanej ochrony jest uzależniony od wystąpienia jednego z trzech enumeratywnie wskazanych zdarzeń: nieszczęśliwego wypadku, nieszczęśliwego wypadku, który miał miejsce na terenie gospodarstwa rolnego, i wypadku komunikacyjnego. Ponadto ubezpieczenie obejmuje zakresem ochrony następujące grupy zdarzeń: pobyt dziecka w szpitalu, koszty leczenia, koszty leczenia stomatologicznego, operacje chirurgiczne, koszty zakupu sprzętu rehabilitacyjnego oraz środków pomocniczych.

W zakresie mogących wystąpić chorób zdarzeniami chronionymi w ubezpieczeniu są: pobyt dziecka w szpitalu, poważne zachorowanie dziecka, zdiagnozowanie sepsy i wady wrodzonej serca. Jednak nie w każdym wymienionym wyżej przypadku dojdzie do powstania odpowiedzialności ubezpieczyciela. Towarzystwo ubezpieczeniowe określiło bowiem dokładnie granice odpowiedzialności i przesłanki pozbawiające ubezpieczonego prawa do świadczeń.

Zakres zdarzeń chronionych i ich skutków istotnie różni się więc w porównywanych ubezpieczeniach. Wadą rozwiązań ubezpieczenia społecznego jest zbyt ogólna definicja wypadku przy pracy oraz niejednoznaczna definicja choroby i choroby zawodowej. Wielokrotnie podkreślano w doktrynie

${ }^{28}$ Umowa grupowego ubezpieczenia nie została dotąd prawnie uregulowania. Zob. A. Daszewski, A. Dąbrowska, O potrzebie zmiany przepisów kodeksu cywilnego o umowie ubezpieczenia w kontekście uregulowania ubezpieczeń grupowych, w: M. Serwach (red.), Rynek ubezpieczeniowy - nadregulacja czy niedoregulowanie, Łódź 2014, s. 177.

29 Zgodnie z $§ 2$ pkt 11 OWU. Ogólne warunki umowy nie zostały zamieszczone stronie internetowej KRUS, widnieje tam tylko ulotka informacyjna. 
trudności występujące w przypadku postępowań kwalifikacyjnych zdarzeń wypadkowych ${ }^{30}$. Problemem może być też jednak enumeratywne wyliczenie chronionych zdarzeń i ich skutków w analizowanym ubezpieczeniu gospodarczym. Odbywa się to poprzez sztywne i szczegółowe określenie granic ochrony, a co za tym idzie - granic odpowiedzialności towarzystwa ubezpieczeniowego.

Zakres podmiotowy rolniczego ubezpieczenia społecznego obejmuje przede wszystkim samozatrudnionych rolników ${ }^{31}$, pomocników rolnika i członków rodziny rolnika. Domownikiem zgodnie z definicją ustawową może być osoba, która ukończyła 16 lat $^{32}$. Pomimo zgłaszania postulatu rozszerzenia katalogu ubezpieczonych o młodsze dzieci rolnika ustawodawca nie zdecydował się tego dokonać.

Ustawodawca w $2018 \mathrm{r}^{33}$ wprowadził jednak do katalogu podmiotowego pomocnika rolnika, starając się uwzględniać zmieniające się okoliczności społeczno-gospodarcze. Nie objął natomiast ochroną wszystkich członków rodziny rolnika pracujących w działalności rolniczej, pomimo normy konstytucyjnej uznającej gospodarstwa rodzinne za podstawę ustroju rolnego.

Wskazane wyżej osoby podlegają ubezpieczeniu wypadkowemu, jeżeli nie są objęte innym ubezpieczeniem społecznym lub nie mają ustalonego prawa do emerytury/renty albo ustalonego prawa do świadczeń z ubezpieczeń społecznych. O katalogu ubezpieczonych w szczególnym subsystemie rolniczego ubezpieczenia społecznego decyduje nie tylko przynależność do wskazanej grupy zawodowej, warunki pracy w działalności rolniczej, lecz także praca rodziny i konieczność jej ochrony w wielopokoleniowym gospodarstwie rolnym. Do najważniejszych atrybutów rolnictwa rodzinnego należą: związek gospodarstwa rolnego z domowym, więzi rodzinne i ochrona rodziny, wielopokoleniowość rodzin rolniczych, rodzinne zasoby pracy, ochrona zdolności do pracy w rolnictwie, stosunki własnościowe, rodzinne dochody oraz stosunki z następcą prawnym.

Oprócz ubezpieczenia obowiązkowego ustawodawca przewidział także możliwość przystąpienia do ubezpieczenia na wniosek. Wniosek o ubezpie-

${ }^{30}$ B. Wierzbowski, Wypadek przy pracy rolniczej w świetle orzecznictwa sadowego, „Ubezpieczenia w Rolnictwie. Materiały i Studia” 2000, nr 2, s. 79; W. Kobielski, Wypadki przy pracy i choroby zawodowe rolników - wybrane problemy, „Ubezpieczenia w Rolnictwie. Materiały i Studia” 2005, nr 2-3, s. 31; I. Lis, Wybrane zagadnienia wypadków przy pracy rolniczej, „Prawo Rolne" 1991, nr 1, s. 23.

${ }^{31}$ Także pod pewnymi warunkami swoistą kategorię podmiotów dwuzawodowców: rolników-przedsiębiorców.

${ }^{32}$ Zgodnie z art. 6 pkt 2 u.u.s.r.

${ }^{33}$ Ustawa z 13 kwietnia 2018 r. o zmianie ustawy o ubezpieczeniu społecznym rolników oraz niektórych innych ustaw (Dz. U. poz. 858). 
czenie fakultatywne może złożyć zainteresowany albo rolnik, na którego rachunek dana osoba pracuje. Należy przy tym zaznaczyć, że ubezpieczony wnioskowo może w każdej chwili od ubezpieczenia odstąpićc ${ }^{34}$. Ubezpieczeniem wypadkowym na wniosek może być objęty inny rolnik lub domownik, jeżeli prowadzona przez niego działalność rolnicza stanowi stałe źródło jego utrzymania, a także osoba, która będąc rolnikiem, przeznaczyła grunty prowadzonego gospodarstwa rolnego do zalesienia. Jeżeli wymienione wyżej osoby podlegają innemu ubezpieczeniu społecznemu albo mają ustalone prawo do emerytury bądź renty lub innych świadczeń z ubezpieczeń społecznych, mogą zostać objęte ubezpieczeniem wypadkowym jedynie w ograniczonym zakresie. Granicę przyznanej ochrony w przypadku wystąpienia zdarzenia wypadkowego wyznacza jedynie uprawnienie do jednorazowego odszkodowania określonego w art. 9 pkt 1 u.u.s.r. ${ }^{35}$

Katalog podmiotowy w opłacanym przez FSUSR grupowym ubezpieczeniu NNW obejmuje wyłącznie dzieci rolników do ukończenia 16. roku życia. Konkretyzując zakres podmiotowy, ubezpieczenie obejmuje dziecko rolnika pozostające we wspólnym gospodarstwie domowym z rodzicami lub opiekunami prawnymi, z których przynajmniej jedno jest objęte ubezpieczeniem społecznym rolników w pełnym zakresie w Kasie Rolniczego Ubezpieczenia Społecznego ${ }^{36}$. Po osiągnięciu przez dziecko wieku 16 lat ochrona ubezpieczenia gospodarczego ustaje ${ }^{37}$. Skutek taki przynosi także wyczerpanie sumy ubezpieczenia oraz wystąpienie śmierci ubezpieczonego dziecka.

5. Katalog świadczeń należy zatem rozpatrywać w odniesieniu do społecznego ubezpieczenia wypadkowego i chorobowego. Zadanie to jest jednak utrudnione z uwagi na złożoność konstrukcji świadczeń z ubezpieczenia rolniczego. Wynika ona z zależności finansowania świadczeń i polega na występowaniu silnego powiązania pomiędzy ubezpieczeniami ${ }^{38}$. Świadczenia można podzielić na grupy świadczeń związane z chorobą i wypadkiem oraz świadczenia powypadkowe. Podstawowym świadczeniem wypadkowym jest jednorazowe odszkodowanie z tytułu śmierci oraz trwałego i długotrwałego

${ }^{34}$ Nieopłacenie składki przez ubezpieczonego wnioskowo rolnika może być traktowane równoznacznie z odstąpieniem od ubezpieczenia. Zob. art. 3 u.u.s.r.

35 Jednorazowe odszkodowanie $\mathrm{z}$ tytułu stałego lub długotrwałego uszczerbku na zdrowiu bądź śmierci wskutek wypadku przy pracy rolniczej lub rolniczej choroby zawodowej, zwane dalej jednorazowym odszkodowaniem.

${ }^{36}$ Zgodnie z $\S 2$ pkt 33 OWU.

37 Zob. $\S 8$ pkt 2 OWU.

${ }^{38}$ D. Puślecki, Społeczne ubezpieczenie wypadkowe rolników. Zagadnienia prawne, Warszawa 2011, s. $161 \mathrm{i} \mathrm{nn}$. 
uszczerbku na zdrowiu bądź choroby zawodowej. W przypadku ubezpieczenia chorobowego jest to zasiłek chorobowy. Do grupy świadczeń powypadkowych należą natomiast: zasiłek chorobowy związany z wypadkiem przy pracy, renta $z$ tytułu niezdolności do pracy, renta szkoleniowa oraz renta rodzinna. Nie wszystkie te świadczenia przysługują zatem z ubezpieczenia wypadkowego.

Jeśli chodzi o wysokość kwot najważniejszych świadczeń z ubezpieczenia społecznego, to za każdy procent uszczerbku na zdrowiu poszkodowany może otrzymać 809 zł. W przypadku wystąpienia choroby może wystąpić o zasiłek chorobowy - świadczenie w niezmienionej od lat wysokości 10 zł za każdy dzień niezdolności do pracy ${ }^{39}$. Na marginesie warto wspomnieć o wysokości renty z tytułu niezdolności do pracy, określonej obecnie na kwotę $972,40 \mathrm{zf}^{40}$.

O wysokości uzyskiwanych świadczeń z ubezpieczeń gospodarczych decyduje określona $\mathrm{w}$ umowie suma ubezpieczenia. Zgodnie $\mathrm{z}$ umową zawartą 1 stycznia 2020 r. między posiadającym osobowość prawną Zarządem Funduszu Składkowego a Pocztowym Towarzystwem Ubezpieczeń Wzajemnych kwota ta została określona na 67 tys. $\mathrm{z}^{41}$. Nie jest to jednak jedyny wyznacznik wysokości uzyskiwanych świadczeń, ponieważ umowa ubezpieczenia wskazuje odrębne kwoty dla poszczególnych zdarzeń chronionych.

Świadczenia z ubezpieczenia NNW obejmują przede wszystkim odszkodowania z tytułu śmierci ubezpieczonego dziecka wskutek nieszczęśliwych wypadków. Towarzystwo wypłaci świadczenie w wysokości $100 \%$ sumy ubezpieczenia (67 tys. zł) pod warunkiem, że nieszczęśliwy wypadek miał miejsce w okresie ubezpieczenia, śmierć dziecka nastąpiła w okresie 18 miesięcy od daty zajścia zdarzenia oraz między nieszczęśliwym wypadkiem a śmiercią istniał związek przyczynowo-skutkowy.

O tym, że polisa jest skierowana do dzieci rolników, może świadczyć wyodrębniona grupa nieszczęśliwych (śmiertelnych) wypadków na terenie gospodarstwa rolnego. Pojęcie gospodarstwa rolnego zostało tu jednak odmiennie zdefiniowane niż w ustawie o ubezpieczeniu społecznym rolników. Zgodnie bowiem z $§ 2$ pkt 6 OWU za gospodarstwo rolne uważa się obszar gruntów sklasyfikowanych w ewidencji gruntów i budynków jako użytki rolne lub jako grunty zadrzewione i zakrzewione na użytkach rolnych, o łącznej powierzchni przekraczającej 1 ha lub 1 ha przeliczeniowy, z wyjątkiem

\footnotetext{
39 Wysokość świadczeń z ubezpieczenia społecznego rolników - stan na 1 marca 2020 roku, www.krus.gov.pl [dostęp: 15.05.2020].

${ }^{40}$ Wybrane kwoty świadczeń z ubezpieczenia społecznego rolników, www.krus.gov.pl [dostęp: 2.05.2020].

${ }^{41}$ Dane uzyskane z Centrali KRUS w Warszawie.
} 
gruntów zajętych na prowadzenie działalności gospodarczej innej niż działalność rolnicza, a także obszar takich gruntów, niezależnie od powierzchni, jeżeli jest prowadzona na nim produkcja rolna, stanowiąca dział specjalny produkcji rolnej w rozumieniu przepisów o podatku dochodowym od osób fizycznych oraz przepisów o podatku dochodowym od osób prawnych.

Świadczenie w wysokości 50\% sumy ubezpieczenia jest dodatkowym odszkodowaniem do świadczenia z tytułu nieszczęśliwego wypadku i sumuje się. W razie wystąpienia takiego zdarzenia rodzicom dziecka może zatem przysługiwać świadczenie w wysokości 105 tys. zł. Konieczne jest jednak spełnienie dodatkowych wymogów umownych, dotyczących wystąpienia przesłanki terenu gospodarstwa rolnego, śmierci w terminie do 18 miesięcy od wypadku i występowania adekwatnego związku przyczynowo-skutkowego między wypadkiem a śmiercią dziecka.

Trzecim zdarzeniem chronionym jest śmierć dziecka w nieszczęśliwym wypadku komunikacyjnym. Ubezpieczyciel definiuje takie zdarzenie jako wywołany ruchem pojazdu wypadek, w którym ubezpieczony uczestniczył jako pasażer, osoba kierująca pojazdem, pieszy lub rowerzysta. Przewidziane w tym przypadku świadczenie ma również charakter dodatkowy i zostało określone w wysokości 20\% sumy ubezpieczenia. Zostanie ono wypłacone przy wystąpieniu podobnych jak wspomniane powyżej obwarowań dodatkowych. Kwota świadczenia w takim przypadku została określona w wysokości 80400 zł.

W związku z przedstawionymi zdarzeniami chronionymi pojawia się pytanie, którą konstrukcję odpowiedzialności przyjmie ubezpieczyciel, jeżeli wypadek komunikacyjny wystąpi na terenie gospodarstwa rolnego. Zdarzenia takie bowiem się zazębiają i nie może wtedy dojść do kumulacji świadczeń. Analizując zapisy OWU, można sądzić, że ubezpieczyciel wypłaci wówczas wyższe świadczenie z tytułu wystąpienia nieszczęśliwego wypadku na terenie gospodarstwa rolnego ${ }^{42}$.

Kolejną grupę odszkodowań stanowią świadczenia z tytułu odniesienia przez dziecko uszczerbku na zdrowiu. Umowa ubezpieczenia, w przeciwieństwie do ustawy o ubezpieczeniu społecznym rolników, nie posługuje się pojęciem stałego i długotrwałego uszczerbku na zdrowiu i inaczej go definiuje. Wprowadza ona pojęcie trwałego uszczerbku na zdrowiu, określonego jako trwałe, nierokujące poprawy uszkodzenie danego organu, narządu lub układu, polegające na fizycznej utracie tego organu, narządu czy układu lub upośledzeniu jego funkcji ${ }^{43}$. Świadczenie wypłacane będzie za procent

${ }^{42}$ Zgodnie z $§ 4$ ust. 7 OWU.

${ }^{43}$ Zob. § 2 pkt 31 OWU. 
poniesionego uszczerbku, wycenionego na kwotę $670 \mathrm{zl}^{44}$. W przypadku niemożliwości jego orzeczenia ubezpieczyciel wypłaci jednorazową kwotę świadczenia z tytułu uszkodzenia ciała w wysokości 670 zł. Wypłata świadczenia z tytułu trwałego uszczerbku na zdrowiu wyłącza jednak jednorazowe świadczenia z tytułu innych wskazanych w umowie przyczyn ${ }^{45}$.

Wskazane świadczenia są dużo niższe niż w przypadku rolniczego ubezpieczenia społecznego. Świadczenie będzie bowiem wypłacone tylko powyżej 3\% poniesionego uszczerbku na zdrowiu. Jeżeli wielkość uszczerbku będzie zbyt mała, to poszkodowany otrzyma świadczenie jednorazowe -670 zł. Wypłata świadczenia uzależniona jest jednak od spełnienia dodatkowych przesłanek, takich jak: hospitalizacja dziecka albo przyjęcie na SOR i odbycie co najmniej jednej kontrolnej wizyty lekarskiej.

W przypadku wystąpienia u poszkodowanego długotrwałego uszczerbku na zdrowiu powyżej 6 miesięcy - instytucji znanej z rolniczego ubezpieczenia społecznego - dysproporcja w wysokości uzyskanego świadczenia będzie jeszcze większa. Ubezpieczony w takim przypadku z prywatnego ubezpieczenia gospodarczego otrzyma tylko świadczenie jednorazowe w wysokości $670 \mathrm{zł}$.

Poszkodowanemu dziecku mogą zostać przyznane świadczenia jednorazowe z tytułu nieszczęśliwych zdarzeń wskazanych w umowie, obliczane jako wielokrotność określonego w umowie 1\% uszczerbku na zdrowiu. Chodzi o takie zdarzenia, jak: pokąsania, ukąszenia, pogryzienia, ugryzienia - w kwocie jednokrotności świadczenia - 670 zł, zatrucia środkami chemicznymi, grzybami, salmonellą lub trującymi roślinami, porażenia prądem elektrycznym lub piorunem - w wysokości 1340 zł. Warto zauważyć, że $\mathrm{w}$ grupie tej ubezpieczyciel ujął pogryzienie przez zwierzęta. Jest to częste zagrożenie na terenie gospodarstwa rolnego, będące przyczyną wielu wypadków w rolnictwie. Zryczałtowana, bardzo niska kwota świadczenia nie może jednak w wystarczający sposób kompensować poniesionych szkód.

Wyjątek w tej grupie skutków chronionych zdarzeń stanowią oparzenia lub odmrożenia ciała, gdzie świadczenia wypłacane są za każdy stwierdzony procent uszczerbku na zdrowiu powyżej 3\%. Trzeba jednak zaznaczyć, że do uzyskania powyższych świadczeń wymagana jest hospitalizacja poszkodowanego, a przynajmniej zgłoszenie na SOR i wizyta kontrolna. Często także wymagane jest potwierdzenie wystąpienia przyczyny odniesionego uszczerbku przez lekarza prowadzącego.

${ }^{44}$ Powyżej 3\% stwierdzonego uszczerbku na zdrowiu.

${ }^{45}$ Oparzenia lub odmrożenia ciała, pokąsania, ukąszenia, pogryzienia, ugryzienia, zatrucia się środkami chemicznymi, grzybami, salmonellą lub trującymi roślinami, porażenia prądem elektrycznym lub piorunem. 
Najwyższym świadczeniem zryczałtowanym w omawianej grupie, powiązanym jednak z nieszczęśliwym wypadkiem, jest doznanie przez dziecko wstrząśnienia mózgu. Kwota świadczenia określona została na 2680 zł i stanowi czterokrotność stawki podstawowej. Wypłata świadczenia wymaga także spełnienia wskazanych wyżej przesłanek dodatkowych.

Kolejnymi świadczeniami mogącymi przysługiwać poszkodowanemu dziecku są odszkodowanie za pobyt w szpitalu i pokrycie kosztów leczenia. W pierwszym przypadku świadczenie zostało określone, niezależnie, czy będzie wynikiem nieszczęśliwego wypadku, czy choroby, na kwotę 70 zł dziennie w przypadku nieprzerwanego pobytu przez co najmniej $7 \mathrm{dni}$, do maksymalnie 180 dni w roku. W drugim przypadku jest ono limitowane na sumę 2500 zł i dotyczy leczenia skutków wypadku. Odnosi się to również do stomatologicznych skutków wypadku, ale przy zastrzeżeniu maksymalnej kwoty w wysokości $700 \mathrm{zł} \mathrm{za} \mathrm{odbudowę} \mathrm{jednego} \mathrm{zęba}{ }^{46}$.

Zakup sprzętu pomocniczego i rehabilitacyjnego dla poszkodowanego dziecka również został ograniczony do kwoty 2500 zł. Należy zauważyć, że są to limity wskazane do określonej kwoty. Świadczenie pokrywa zatem tylko rzeczywiście poniesione koszty, które zostały udokumentowane w postaci rachunków. Natomiast w przypadku sprzętu rehabilitacyjnego świadczenie to wydaje się zbyt nisko określone.

Wysoko wycenione zostały przez ubezpieczyciela kwoty świadczeń z tytułu wystąpienia u dziecka sepsy i wrodzonej wady serca zdiagnozowanych po raz pierwszy w okresie ubezpieczenia - 13400 zł. Z kolei wypłacenie świadczenia $\mathrm{z}$ tytułu konieczności przeprowadzenia operacji chirurgicznych w związku z zaistniałym wypadkiem oraz świadczenia z tytułu poważnego zachorowania określono na kwotę $6400 \mathrm{zl}$.

6. Wyłączenie odpowiedzialności KRUS w ubezpieczeniu społecznym następuje wówczas, gdy wystąpią określone ustawowo przesłanki pozbawiające prawa do świadczeń. Chodzi tu głównie o umyślność w działaniu, rażące niedbalstwo, stan nietrzeźwości, znajdowanie się pod wpływem substancji odurzających, a także zwłoka w zgłoszeniu zdarzenia. W ubezpieczeniu NNW przesłanki pozbawiające prawa do świadczeń zostały enumeratywnie wyliczone aż w piętnastu punktach. Oprócz działań wojennych i aktów przemocy wymienia się tu samookalecznie, samobójstwo czy popełnienie przestępstwa i wystąpienie choroby psychicznej. Wspomniana przesłanka nietrzeźwości pozbawiająca świadczenia w KRUS została w analizowanym ubezpieczeniu rozszerzona o stan po spożyciu alkoholu albo znajdowania

${ }^{46}$ Zgodnie z $§ 4$ ust. 39 OWU. 
się pod wpływem środków odurzających, substancji psychotropowych lub środków zastępczych, albo leków na receptę nieprzepisanych przez lekarza lub użytych niezgodnie z zaleceniem lekarza, a nawet zatrucia alkoholem, tymi środkami i lekami.

Nie można też pominąć przesłanki pozbawiającej świadczenia dziecka rolnika w przypadku kierowania przez nie pojazdów bez uprawnień, jeżeli $\mathrm{z}$ tego powodu wydarzył się wypadek. W przypadku prowadzenia pojazdu niezarejestrowanego albo niedopuszczonego do ruchu ubezpieczyciel będzie oceniał, na ile do wystąpienia zdarzenia przyczynił się jego stan techniczny. Istotną przesłanką wyłączającą odpowiedzialność ubezpieczyciela są wypadki dzieci w wieku do 10 lat, poruszających się na rowerach po drogach publicznych bez opieki osoby dorosłej.

Warto też zwrócić uwagę na pozbawienie prawa do świadczeń w wypadkach powstałych podczas wyczynowego uprawiania sportu oraz sportu wysokiego ryzyka. Pozostałe przesłanki dotyczą skażenia radioaktywnego, działania energii jądrowej, wykrycia chorób u dziecka przed okresem ubezpieczenia, zdiagnozowania w okresie trwania ochrony u dziecka HIV czy AIDS oraz udziału dziecka w rozruchach bójkach, blokadzie dróg czy akcjach protestacyjnych.

Mając na uwadze wymienione przesłanki pozbawienia prawa do świadczeń, można stwierdzić, że ubezpieczyciel wprowadził dość szeroki ich katalog. Są to niejednokrotnie przypadki, kiedy wystąpi zdarzenie ubezpieczeniowe, choroba czy nieszczęśliwy wypadek, dziecko dozna obrażeń, a mimo to świadczenie nie zostanie wypłacone. O ile w przypadku umyślnego działania czy samookaleczenia przesłanki nie powinny budzić wątpliwości, o tyle w niektórych sytuacjach wyłączenie odpowiedzialności ubezpieczyciela powinno skłonić do refleksji.

Szczególnie istotne są przypadki wyłączenia niektórych wypadków komunikacyjnych z udziałem ciągników i maszyn rolniczych, w praktyce często obsługiwanych przez dzieci, czy wypadków rowerowych dzieci do lat 10 na drodze publicznej. Co najmniej zastanawiające jest wyłączenie odpowiedzialności ubezpieczyciela, nazywającego polisę ubezpieczeniem od chorób, w przypadku zakażenia dziecka HIV i AIDS, wystąpienia choroby psychicznej czy zatrucia lekami.

7. Kwestia ubezpieczenia dzieci rolnika pracujących w gospodarstwie na wypadek utraty zdolności do pracy była postulowana od lat. Przyznana dziś ochrona, w postaci nietypowej konstrukcji opłacania ubezpieczenia gospodarczego przez władze Funduszu Składkowego, może sugerować rozwiązanie problemu. Analiza porównawcza obu ubezpieczeń - społecznego 
i gospodarczego - nie pozwala jednak na postawienie takiej tezy. Powyższe rozważania prowadzą do następujących wniosków.

Działania podejmowane przez władze Funduszu Składkowego zasługują na uznanie. Jest to szczególnie ważne w obliczu problemów organizacji dobrowolnych grupowych ubezpieczeń NNW w szkołach. Ze względu na wątpliwości w ochronie ubezpieczonych, które przedstawiła Komisja Nadzoru Finansowego $(\mathrm{KNF})^{47}$, wiele placówek oświatowych wycofało się $\mathrm{z}$ tej praktyki.

Stosunek ubezpieczenia dziecka rolnika powstaje automatycznie z tytułu podlegania jego rodzica albo opiekuna prawnego ubezpieczeniu w KRUS w pełnym zakresie, zgodnie z zasadą solidaryzmu rolników, na podstawie umowy zawartej i samofinansowanej przez FSUSR.

Przyznanie dzieciom wiejskim ochrony ubezpieczenia NNW, opłacanego w praktyce ze składek rolników na ubezpieczenie społeczne, dokonane zostało na zasadzie solidarności grupowej wszystkich rolników ubezpieczonych w KRUS. Ofertę polisy przygotowano specjalnie dla dzieci rolników, o czym świadczy wiele zapisów tego grupowego ubezpieczenia. Ochrona rozciągnięta jest na wszystkie nieszczęśliwe zdarzenia, także te niezwiązane z działalnością rolniczą rodziców. Ochroną objęte są wszystkie dzieci rolników spełniających kryteria umowy. Składka nie jest dodatkowo płatna, a przystąpienie do ubezpieczenia nie wymaga złożenia stosownego wniosku. Przedmiot ochrony i zakres świadczeń jest jednak odmienny od tych przewidzianych w ubezpieczeniu społecznym.

Ubezpieczenie gospodarcze nie chroni zdolności do pracy dziecka, lecz jego życie i zdrowie. Nawet w przypadku rozważań nad dopuszczalnością pracy dzieci w rolnictwie ${ }^{48}$ nie można bagatelizować skali tego zjawiska. Pozbawienie dzieci całkowitej ochrony od wypadków przy pracy powodowało, że wśród pracujących faktycznie w rolnictwie wiele osób było wykluczonych $^{49}$. Ochrona ubezpieczeniowa przyznana w ubezpieczeniu gospodarczym obejmuje dziś jednak głównie szkody na osobie dziecka rolnika.

$\mathrm{Z}$ podobną konstrukcją ochrony mieliśmy do czynienia do $2004 \mathrm{r}$. w KRUS. Nie można zapomnieć, że podstawowym świadczeniem z ubezpieczenia wypadkowego było jednorazowe odszkodowanie. Dzieci nigdy jednak nie były podmiotami ubezpieczonymi w KRUS, a korzystały ze

${ }^{47}$ Komisja Nadzoru Finansowego, Komunikat w sprawie ubezpieczeń NNW dzieci i młodzieży szkolnej lipiec 2017 r., knf.gov.pl [dostęp: 12.05.2020].

${ }_{48}$ M. Skąpski, Wybrane zagadnienia wspótpracy zawodowej ..., s. 42 i nn.

${ }^{49}$ Szerzej: D. Puślecki, Kwestia ochrony osób bliskich rolnikowi od wypadków przy pracy w świetle rozwiqzań ustawy o ubezpieczeniu społecznym rolników, w: Z. Niedbała (red.), Prawo wobec dyskryminacji w życiu społecznym, gospodarczym i politycznym, Warszawa 2011, s. 239 i nn. 
świadczeń z ubezpieczenia rodzica. W przypadku realizacji postulatu objęcia w przyszłości dzieci rolnika ubezpieczeniem w KRUS poszkodowanemu mógłby przysługiwać szerszy katalog świadczeń. Na szczególną uwagę zasługuje tu chociażby prawo do renty z tytułu niezdolności do pracy i prawo do zasiłku chorobowo-wypadkowego. Podobnych świadczeń próżno szukać w analizowanym ubezpieczeniu NNW i w każdym innym ubezpieczeniu gospodarczym.

Warto także zwrócić uwagę na zakres ochrony ex ante ubezpieczenia. Chodzi o działalność prewencyjną prowadzoną przez KRUS mającą na celu ograniczenie liczby wypadków wśród dzieci na wsi. KRUS nie zaprzestała tej działalności nawet po ustawowym pozbawieniu dzieci do lat 16 świadczeń z ubezpieczenia. Jest ona jednak mocno zawężona i opiera się na różnych akcjach informacyjnych, zaznaczaniu problemu podczas dobrowolnych szkoleń dla rolników czy organizowania konkursów dla dzieci. Analizowane ubezpieczenie gospodarcze nie może prawidłowo spełniać tej funkcji.

Poważnym problemem ubezpieczeń gospodarczych jest brak realizacji działalności prewencyjnej. Kwestia ta-oprócz powszechnie występujących niewielkich sum ubezpieczenia określanych w polisach - ma znaczenie w przypadku ochrony w zakresie NNW. Zagadnienie to zostało poruszone w 2017 r. przez $\mathrm{KNF}^{50}$.

Określając zakres przyznanej aktualnie ochrony ubezpieczeniowej dzieciom pracującym na terenie gospodarstwa rolnego, należy zwrócić uwagę na zdarzenia nieszczęśliwe, zagrażające życiu i zdrowiu oraz niektóre choroby. Ubezpieczyciel w wyraźny sposób chroni, poprzez podniesienie sumy ubezpieczenia, zdarzenia występujące na terenie gospodarstwa rolnego (wypadki, zdarzenia śmiertelne). Zakres chronionych zdarzeń obejmuje także wypadki przy pracy rolniczej z art. 11 u.u.s.r., mimo że ubezpieczenie gospodarcze odmiennie definiuje teren gospodarstwa rolnego. Warto jednak zauważyć, że obecnie w ubezpieczeniu społecznym przesłanki miejscowe wystąpienia zdarzenia wypadkowego straciły na znaczeniu, a liczy się wykazanie, że czynność, którą wykonywał poszkodowany, była związana $\mathrm{z}$ prowadzoną działalnością rolniczą lub pozostawała $\mathrm{w}$ związku z tymi czynnościami.

Ubezpieczenie gospodarcze obejmuje dzieci szerszą ochroną niż art. 11 u.u.s.r., gdyż za chronione uznaje ponadto zawał serca i udar mózgu, które są wywoływane właściwościami organizmu i stanowią wewnętrzną przyczynę zdarzenia wypadkowego. Jednak w odniesieniu do chorób ochrona została zawężona do tych wskazanych w umowie z ograniczeniami czasu

\footnotetext{
${ }^{50} \mathrm{KNF}$, Komunikat w sprawie ubezpieczeń NNW...
} 
ich zdiagnozowania. Takiego rozwiązania brakuje w ubezpieczeniu chorobowym w KRUS ${ }^{51}$.

Ubezpieczenie NNW chroni dzieci, które uległy wypadkom komunikacyjnym, jednak tylko wówczas, gdy dziecko było pasażerem. Natomiast gdy dziecko prowadziło pojazd i stało się ofiarą wypadku, odpowiedzialność może zostać ograniczona, a nawet całkowicie wyłączona, jak w przypadku najmłodszych rowerzystów poruszających się bez opieki po drogach publicznych.

Wypadki komunikacyjne w KRUS są w ograniczonym zakresie chronione ubezpieczeniem wypadkowym. Chodzi tu tylko o wypadki związane z prowadzoną działalnością rolniczą. Kwalifikacja zdarzenia wypadkowego, które nastąpiło w drodze ubezpieczonego do gospodarstwa i w drodze powrotnej, w praktyce często budzi poważne wątpliwości. Problemy pojawiają się najczęściej przy ocenie drogi pokonywanej przez ubezpieczonego. Powinna być ona nieprzerwana (chyba że przerwa była uzasadniona życiowo), najkrótsza lub najdogodniejsza ze względów komunikacyjnych ${ }^{52}$.

O zakresie przyznanej ochrony ubezpieczeniowej świadczy jakość uzyskiwanych świadczeń. W odniesieniu do wypadków w ubezpieczeniu NNW świadczenia mogą przysługiwać z tytułu śmierci dziecka, uszczerbku na zdrowiu, uszkodzenia ciała, porażenia prądem, zatrucia, pokąsania, ukąszenia, pogryzienia, ugryzienia dziecka przez zwierzęta, powypadkowego wstrzą́nienia mózgu, oparzenia i odmrożenia ciała.

Porównując sumę ubezpieczenia 67000 zł ze świadczeniem jednorazowego odszkodowania z tytułu śmierci w KRUS w kwocie 80900 zł, można odnieść błędne wrażenie, że KRUS przewiduje świadczenie wyższe. Wypłata świadczenia z ubezpieczenia NNW może być jednak powiększona do 105000 zł, jeżeli wypadek śmiertelny zdarzy się na terenie gospodarstwa rolnego, albo do 80400 zł, jeżeli śmierć dziecka nastąpi w wypadku komunikacyjnym. Nie ulega wątpliwości, że świadczenie w pierwszym przypadku jest o 23 p.p. wyższe. Ubezpieczenie NNW bardziej zatem chroni rodzinę dziecka $\mathrm{z}$ tytułu jego śmierci niż w analogicznej konstrukcji, która mogłaby przysługiwać dzieciom w KRUS.

${ }^{51}$ Ograniczenie występuje tu tylko w zakresie chorób zawodowych.

52 W myśl § 14 rozporządzenia Ministra Pracy, Płac i Spraw Socjalnych oraz Ministra Zdrowia i Opieki Społecznej z 17 października 1975 r. w sprawie zasad i trybu orzekania o uszczerbku na zdrowiu oraz wypłacania świadczeń z tytułu wypadku przy pracy w drodze do pracy i z pracy oraz z tytułu chorób zawodowych (Dz. U. Nr 36, poz. 199) uważa się, że wypadek nastąpił w drodze do pracy lub z pracy, jeżeli droga do pracy albo z pracy była drogą najkrótszą i nie została przerwana lub gdy droga ta została przerwana, jeżeli przerwa była życiowo uzasadniona, a czas jej nie przekraczał granicy potrzeby, albo gdy droga nie była najkrótsza, ale była dla pracownika najdogodniejsza ze względów komunikacyjnych. 
Nie można jednak zapominać, że ochrona ubezpieczeniowa sprowadza się w większości przypadków do wypłaty odszkodowań za każdy procent uszczerbku na zdrowiu. Tu pomimo wcześniejszej przewagi ochrona ubezpieczyciela gospodarczego jest niewystarczająca. Kasa wypłaca obecnie świadczenie o 139 zł wyższe za każdy procent odniesionego uszczerbku. Świadczenie NNW przysługiwać będzie natomiast dopiero powyżej stwierdzenia u poszkodowanego 3\% uszczerbku na zdrowiu. Warto przy tym zaznaczyć, że większość wypadków przy pracy w rolnictwie skutkuje obecnie uszczerbkiem na zdrowiu do $5 \%{ }^{53}$.

Ubezpieczyciel gospodarczy wypłaci niskie świadczenie w kwocie 70 zł za dzień pobytu w szpitalu do analogicznego bardzo niskiego świadczenia chorobowego 10 zł dziennie w KRUS, niezależnie od tego, czy poszkodowany był hospitalizowany. Należy jednak zauważyć, że świadczenie NNW poszkodowany może otrzymać tylko w przypadku niektórych chorób.

Jeśli chodzi o świadczenia ryczałtowo wyliczane przez ubezpieczyciela gospodarczego jako wielokrotność kwoty podstawowej określonej na 670 zł, to trzeba stwierdzić, że są one limitowane i niezwiązane $\mathrm{z}$ faktycznym procentowym uszczerbkiem na zdrowiu. Nie rekompensują zatem rzeczywiście poniesionych szkód i nie zapewniają właściwej ochrony ubezpieczonemu.

$\mathrm{Z}$ ubezpieczeniami gospodarczymi wiąże się ryzyko dotyczące gwarancji wypłaty świadczenia. Część z niego może przejąć Ubezpieczeniowy Fundusz Gwarancyjny, ale możliwa jest także coroczna zmiana warunków umowy. Warto przypomnieć, że analizowane warunki ubezpieczenia zostały zapisane drobną czcionką na 10 stronach i zawierają liczne wyjątki od ogólnych zasad odpowiedzialności ubezpieczyciela. Kwoty wyliczonych świadczeń również co roku mogą się zmieniać, i to nie zawsze na korzyść ubezpieczonego. Nie daje to zatem gwarancji przyznanej ochrony.

Reasumując, należy stwierdzić, że mimo niewielkiej przewagi w niektórych aspektach protekcji grupowe ubezpieczenie gospodarcze ${ }^{54}$ nie zapewnia właściwej ochrony dzieciom pracującym w gospodarstwach rolnych. Przeprowadzona analiza wykazała, że największym mankamentem obecnego rozwiązania jest brak ochrony zdolności do pracy przyszłych rolników. Nie realizuje zatem w wystarczającym stopniu funkcji prewencyjnej. Ochrona sprowadza się przede wszystkim do likwidacji szkód na osobie. Wysokość uzyskiwanych świadczeń z tytułu uszczerbku na zdrowiu jest dużo niższa w porównaniu ze świadczeniami wypłacanymi dziś przez KRUS. Poszkodowany nie ma odpowiedniego dostępu do świadczeń rehabilitacyjnych i do

${ }^{53}$ Raport z wypadków i chorób zawodowych KRUS za 2019 r., www.krus.gov.pl [dostęp: 20.05.2020].

${ }^{54}$ M. Fras, Grupowe ubezpieczenie, s. 51. 
świadczeń rentowych w przypadku stałej utraty zdolności do pracy. Limity przyjęte w innych świadczeniach, liczne zawężenia i wyłączenia odpowiedzialności ubezpieczyciela, możliwość corocznej zmiany warunków ochrony potwierdzają tylko postawioną tezę. Stanowiska tego nie może zmienić wyższe niż w przypadku KRUS odszkodowanie z tytułu śmierci dziecka na terenie gospodarstwa rolnego.

Przyjętych rozwiązań nie można jednak oceniać do końca krytycznie. $\mathrm{Z}$ braku innej możliwości dzieci pracujące w rolnictwie mogą liczyć chociaż na namiastkę ochrony ubezpieczeniowej. Należy pamiętać, że analizowane rozwiązanie zostało wprowadzone po 12 latach przerwy w ochronie dzieci. Zarząd Funduszu Składkowego za pomocą rozwiązania obwodowego stara się więc uporać z problemem wypadkowości wśród dzieci w rolnictwie. Natomiast w zakresie ochrony ich zdolności do pracy kwestia ta nadal pozostaje otwarta i wymaga nowych rozwiązań systemowych w ramach ubezpieczenia w KRUS.

Ubezpieczenia gospodarcze mogą chronić dzieci na wypadek wystąpienia nieszczęśliwych zdarzeń losowych. Przyjęta konstrukcja zapewnia dziś taką ochronę większości wiejskich dzieci. Poza sumą odszkodowań z tytułu śmierci i śmiertelnych wypadków komunikacyjnych nie jest ona jednak właściwie realizowana. Konieczne jest wzmocnienie ochrony zwłaszcza w przypadku wystąpienia uszczerbków na zdrowiu chronionych za pomocą zryczałtowanych kwot odszkodowań.

Ubezpieczenie powinno zapewnić właściwą realizację funkcji ochronnej, kompensacyjnej, gwarancyjnej i prewencyjnej. W odniesieniu do osób najmłodszych, przyszłych rolników, zadanie ochrony ich zdolności produkcyjnych nabiera szczególnego znaczenia. Ubezpieczenia gospodarcze mogą mieć charakter wspomagający, uzupełniając ochronę rolniczego ubezpieczenia społecznego. Tak szeroko określony zakres ochrony w przypadku dzieci rolnika determinuje dziś różne zagrożenia występujące w działalności rolniczej.

\title{
ACCIDENT AND SICKNESS INSURANCE FOR CHILDREN OF FARMERS INSURED IN THE AGRICULTURAL SOCIAL INSURANCE FUND
}

\author{
Summary
}

The article provides an answer to the question to what extent economic insurance provides protection against the effects of accidental events to children who help their parents in agricultural activity. It compares the scope of protection granted in insurance for children against the consequences of accidents and certain diseases with the solutions adopted in agricultural social insurance. As has been found, despite the small advantage in some aspects 
of protection, the group economic insurance cannot provide adequate protection for children if they become unable to work. The insurance does not sufficiently perform a preventive function, and the amount of health benefits obtained is much lower than those paid by the Agricultural Social Insurance Fund. However, in the absence of any other option, children working in agriculture may count on at least a substitute for insurance protection. Yet, economic insurance should have a supporting character, supplementing the scope of protection provided by the agricultural social insurance scheme.

\title{
L'ASSICURAZIONE CONTRO GLI INFORTUNI E LE MALATTIE PER I FIGLI DEGLI AGRICOLTORI ASSICURATI PRESSO LA CASSA DELLE ASSICURAZIONI SOCIALI PER GLI AGRICOLTORI
}

\author{
Riassunto
}

L'articolo fornisce una risposta alla domanda in che misura le assicurazioni private riescano a tutelare i figli, i quali aiutano i genitori a svolgere l'attività agricola, contro le conseguenze di eventi casuali. Contiene un'analisi comparativa della protezione prevista nell'assicurazione contro gli infortuni e alcune malattie dei bambini, e delle soluzioni adottate nell'assicurazione sociale agricola. Dall'analisi svolta risulta che, nonostante un leggero vantaggio sotto alcuni aspetti, l'assicurazione privata collettiva non può fornire una tutela adeguata per i figli degli agricoltori in caso di perdita della capacità lavorativa. L'assicurazione non adempie sufficientemente alla funzione di prevenzione e gli importi delle prestazioni ricevute per danni alla salute sono significativamente inferiori rispetto a quelli erogati dalla Cassa delle assicurazioni sociali per gli agricoltori. Tuttavia, per mancanza di altre opzioni, i figli impegnati nell'attività agricola si ritrovano costretti a usufruire di un sostituto della tutela assicurativa. Ciò nonostante, le assicurazioni private dovrebbero essere di supporto, a completamento della copertura assicurativa sociale agricola. 